\title{
Highly Selective Derivative Spectrophotometry for Determination of Nickel Using 1-(2-Pyridylazo)-2-naphthol in Tween 80 Micellar Solutions
}

\author{
Habibollah Eskandari \\ Department of Chemistrv. Faculn of Basic Sciences, University of Mohaghegh . Ardebili. Ardebil 179, Iran \\ Received September 16, 2003
}

\begin{abstract}
A spectrophotometric and first derivative spectrophotometric method was developed in aquatic Tween 80 micellar solutions for selective determination of nickel without using any pre-separation step. 1-(2-Pyridylazo)2-naphthol (PAN), as a sensitive chromogenic complexing agent formed a red-colored Ni(II)-PAN complex in Tween 80 media with satisfactory' solubility and stability. Conditions such as pH. PAN concentration. type and concentration of micellizing agent were optimized. Molar absorptivity of Ni-PAN complex was found $4.62 \times 10^{4} \mathrm{~L} \mathrm{~cm}^{-1} \mathrm{~mol}^{-1}$ at $569 \mathrm{~nm}$. under the optimum condition. Calibration graphs were derived by zero. first and second derivative spectrophotometry at mavimum wavelengths of 569.578 and $571 \mathrm{~nm}$ with linear ranges of 30-1800. 20-2500 and 30-2000 $\mathrm{ng} \mathrm{mL}^{-1}$. respectively. Precision as standard deviation as well as accuracy as recovery percent were in the range of $1-20 \mathrm{ng} \mathrm{mL}^{-1}$ and $93.3-103.3 \%$. respectively, for the entire of the linear ranges. Spectrophotometric detection limit was $3 \mathrm{ng} \mathrm{mL}^{-1}$ and effects of diverse ions on the first derivative determination of nickel were studied to investigate selectivity of the method. Interferences of cobalt and copper on the nickel determination were prevented using o-phenanthroline as masking agent. The recommended procedures were applied to the various sy nthetic and stainless steel alloyss. tea leaves and human hair. with satisfactory results.
\end{abstract}

Key Words : Derivative spectrophotometry, Nickel. PAN. Tween 80

\section{Introduction}

Researchers have become widely interested in the chemistry of nickel bio-complexes that are active molecules in the biological and life sciences. This is largely due to the discovery of some important bio-active enzymes. ${ }^{1-3}$ There are six nickel enzymes discovered so far, which are: urease. ${ }^{+}$ $\mathrm{NiFe}$ hydrogenases, methyl coenzyme $\mathrm{M}$ reductase. ${ }^{5}$ carbon monoxide delydrogentase. ${ }^{6}$ acetyl coenzyme A synthase, ${ }^{7}$ and more recently. nickel superoxide dismutase (NiSOD) ${ }^{8.5}$ Urease is considered to be essential to plants and some domestic animals. The necessity of nickel in humans has not been demonstrated. More attention has been focused on the toxicology of nickel in low concentrations. such as the fact that nickel can cause allergic reactions and that certain nickel compounds may be carcinogenic. ${ }^{10}$

Nickel is one of the essential components of some important alloys. One of the best known magnetic alloys is alnico, a steel containing. as its name implies. aluminium and nickel, as well as cobalt. It is used for permanent magnets which are up to 25 times more powerful than ordinary steel magnets. Monel $(68 \% \mathrm{Ni}, 32 \% \mathrm{Cu}$. traces of $\mathrm{Mn}$ and $\mathrm{Fe}$ ) is used in apparatus for handling corrosive materials such as $\mathrm{F}_{2}$; cupro-nickels (up to $80 \% \mathrm{Cu}$ ) are used for silver coinage; nichrome $(60 \% \mathrm{Ni}, 40 \% \mathrm{Cr})$, which has a very small temiperature coefficient of electrical resistance. and invar, which has a very small coefficient of expansion are the other well-known $\mathrm{Ni}$ alloys. Electroplated nickel is an ideal undercoat for electroplated chromium, and smaller

\footnotetext{
*e-mail: Habibollah-Eskandariatuma.irost.net
}

amounts of nickel are used as cataly sts in the lydrogenation of unsaturated vegetable oils and in storage batteries such as the $\mathrm{Ni} / \mathrm{Fe}$ batteries. The stainless steel industry is the largest user of nickel. both in the primary and recycled forms. ${ }^{11}$

Among various instrumental methods that have been developed or modified for determination of nickel, flame AAS combined with preconcentration by chelating agents or modified resins $\mathrm{s}^{12-15}$ and electrothermal AAS $^{16.17}$ have been widely used. These methods suffer from some limitations in simplicity. analytical time, economics and environmental safety. Spectrophotometric methods often suffer from limitations in sensitivity and selectivity but are widely used due to both the resulting experimental rapidity and simplicity. The selectivity and sensitivity of the spectrophotometric determination methods depend on the type of reaction and cluromogenic reagent used. ${ }^{18}$

In a paper using 2-(5-bromo-2-pyridylazo)-5-diethylaminophenol (Br-PADAP) in Trition X-100 solutions at $\mathrm{pH}$ 5.0-6.0, spectrophotometry and first derivative spectrophotometry were applied to determine nickel in the presence of cobalt. High sensitivity and selectivity in a simple but time consuming $(50 \mathrm{~min})$ manner was observed. The method was applied to some steel alloys. The cobalt interference was removed by first derivative spectrophotometry at zerocrossing wavelength of the cobalt-Br-PADAP complex. The method was one of the best nickel determination methods. ${ }^{19}$

This work reports a simple, sensitive and highly selective method by zero. first and second derivative spectrophotometry for the determination of nickel. The method is based on the complex formation of $\mathrm{Ni}(\mathrm{II})$ with PAN in the Tween 80 micellar media. 


\section{Experimental Section}

Apparatus and Reagents. Absorbance measurements as well as zero, first and second derivative spectra were obtained by a Cecil CE 9020 UV-Vis scanning spectrophotometer equipped with one pair of $10-\mathrm{mm}$ light path quartz matched cells. Measurements of $\mathrm{pH}$ were made using a Metrolm $691 \mathrm{pH}-\mathrm{meter}$ equipped with a glass-saturated calomel combined electrode.

Water used in this work was doubly distilled and all of the reagents used were of analytical grade reagents. A PAN (Merck) solution as $0.20 \%(\mathrm{Wt} / \mathrm{V})$ in ethanol was prepared and used. Standard nickel(II) solution $\left(2000 \mu \mathrm{g} \mathrm{mL} \mathrm{L}^{-1}\right)$ was prepared as a stock solution in a $250 \mathrm{~mL}$ volumetric flask and was then standardized ${ }^{3 i j}$ Working nickel solutions were prepared daily by diluting the appropriate volume of this stock solution with deionized water. Tween 80 . Triton X-100 and sodium dodecylsulfate (SDS) were purchased (Merck) and their solutions as $6.4 \%(\mathrm{Wt} / \mathrm{V})$ were prepared in $250 \mathrm{~mL}$ volumetric flasks. Universal buffers (acetic acid-phosphoric acid-boric acid mixture) at different $\mathrm{pHs}$ were used for this study.

Procedure. $5 \mathrm{~mL}$ Tween 80 in the concentration of $6.4 \%$. one drop of $0.1 \mathrm{M}$ ammonia solution, $0.5 \mathrm{~mL}$ of $0.1 \mathrm{M} \mathrm{o}$ phenantluroline, the required volume of neutralized saniple solution containing nickel. $0.5 \mathrm{~mL}$ of $0.1 \mathrm{M}$ tartrate-fluoride solution and $1.0 \mathrm{~mL}$ of $0.20 \%$ PAN in ethanol were added into a $10.0-\mathrm{mL}$ volumetric flask. After $5 \mathrm{~min}$ standing for completion of conplexation reaction, $0.5 \mathrm{~mL}$ of universal buffer with $\mathrm{pH}$ equal to $\mathrm{L} .89$ was added and the flask was adjusted to the mark with double distilled water. Absorbance of the sample solution was measured against a reagent blank solution at $569 \mathrm{~nm}$ and was then considered for the determination of nickel using a calibration graph prepared in the same manner.

The first and second order derivative spectra of the sample solution were recorded against its reagent blank in the wavelength range of $550-650 \mathrm{~lm}$ with $\Delta \lambda=2 \mathrm{~lm}$ using a scan speed of $200 \mathrm{~mm} / \mathrm{min}$. The first and second derivative analytical signals were at 578 and $571 \mathrm{~mm}$. respectively. Nickel concentration was determined using the first and second derivative spectrophotometric calibration graphs which were prepared in the same manner.

\section{Results and Discussion}

The effects of various parameters on the sensitivity of the nickel determination method was investigated. One at a time optimization procedure was evaluated for obtaining optimum condition.

$\mathrm{pH}$ is one of the most important parameters for this determination. The experiments in various values of $\mathrm{pH}$ show that spectrum of PAN was dependent on $\mathrm{pH}$ but $\mathrm{Ni}$ (II)PAN spectrum was approximately independent of $\mathrm{pH}$. The important spectrophotometric characteristics of $\mathrm{Ni}(\mathrm{II})$-PAN have been given in Table 1 . The shape of absorption spectra. maximum wavelengths and molar absorptivities did not
Table 1. Effect of $\mathrm{pH}$ on the spectral characteristics of Ni(II)-PAN complex

\begin{tabular}{ccc}
\hline & \multicolumn{2}{c}{ Ni(II)-PAN } \\
\cline { 2 - 3 } $\mathrm{pH}$ & $\begin{array}{c}\text { Maximum wavelength } \\
\text { (nm) }\end{array}$ & $\begin{array}{c}\text { Molar absorptivity } \\
\text { L cm }^{-1} \text { mol }^{-1}\end{array}$ \\
\hline 1.81 & 569 & $4.59 \times 10^{4}$ \\
1.89 & 569 & $4.62 \times 10^{4}$ \\
1.98 & 569 & $4.67 \times 10^{4}$ \\
2.09 & 567 & $4.87 \times 10^{4}$ \\
2.21 & 566 & $4.99 \times 10^{4}$ \\
2.56 & 566 & $4.97 \times 10^{4}$ \\
3.29 & 566 & $5.03 \times 10^{4}$ \\
\hline
\end{tabular}

Condition: $10 \mathrm{~mL}$ solution containing 0.010 PAN. $3.2^{\circ}$. Tween 80 . unizersal buffer with difterent $\mathrm{pHs}$ and $10 \mathrm{\mu g} \mathrm{Ni}(\mathrm{II})$.

change considerably when $\mathrm{pH}$ varied in the range of 1.81 3.29. The molar absorptivity of $\mathrm{Ni}(\mathrm{II})$-PAN decreases slightly when $\mathrm{pH}$ is lowered but the spectrum of Ni-PAN does not change considerably when $\mathrm{pH}$ is lowered. In terms of selectivity low $\mathrm{pH}$ is better (to decompose the other formed metal-PAN complexes), but in tems of sensitivity high $\mathrm{pHs}$ are favored. However. selectivity enhancement is preferred. According to these results, $\mathrm{pH}$ value of 1.89 was selected for the next studies.

Various micellizing agents such as Tween 80 . Triton X100 and SDS in concentration of $3.2 \%$ were tested as solubilizing agents. The absorbance of Ni(II)-PAN complex at $569 \mathrm{~nm}$ was measured and was considered for the nickel determination method. Less sensitivity was observed in SDS solution. Nonionic micelles are often preferred to anionic micelles for the determination of metal ions because attraction forces between the negative head of micelles and the positive charge of metal ions causes lower apparent formation constant between metal ions and ligands. ${ }^{21.22}$ Higher stability and faster formation for the $\mathrm{Ni}(\mathrm{II})$ complex was observed in Tween 80 against Triton X-100. Therefore Tween 80 was selected as the micellizing agent for further studies.

The effect of Tween 80 concentration on the sensitivity of the nickel determination was also studied. Tween 80 concentrations in the range of $1.9-3.2 \%$ produce large and constant sensitivities. PAN and its nickel complex precipitated in Tween 80 concentrations less than $1.9 \%$. Tween 80 in $3.2 \%$ concentration was accepted for further studies.

Optimization of PAN concentration was performed spectrophotometrically at $569 \mathrm{~nm}$ by varrying PAN concentration at $\mathrm{pH}$ value of 1.89 and Tween 80 concentration of $3.2 \%$. The obtained results showed that sensitivity was maximum and constant in the PAN concentration range of $0.002-0.02 \%$. PAN precipitated in concentrations higher than $0.02 \% .0 .02 \%$ PAN was selected for further studies.

The effect of ionic strength on the sensitivity of the nickel determination method was investigated. Concentration of sodium chloride and sodium nitrate were tolerated from 0.00 to $0.40 \mathrm{M}$ as ionic buffers but no detectable differences on the sensitivity of the method were observed. 


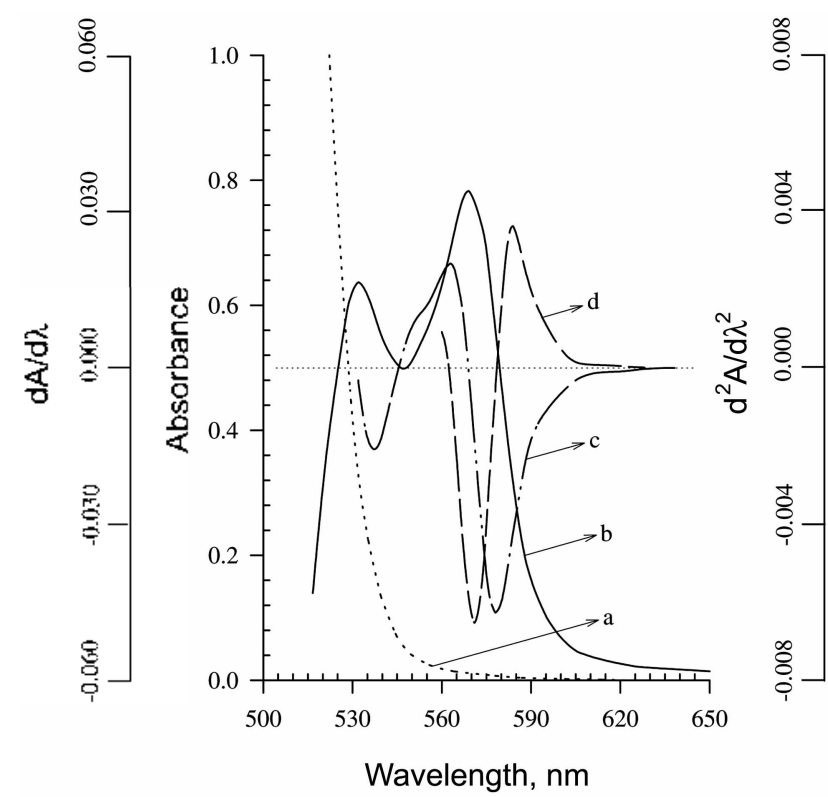

Figure 1. Specirophotometric spectra of a) $P A N$ and b) Ni(II)-PAN complex also c) first and d) second derivative spectra of $\mathrm{Ni}$ (II)-PAN complex. Condition: $10 \mathrm{~mL}$ solution at $\mathrm{pH} \quad \mathrm{I} .89$ containing $3.2 \%$ Tween 80. PAN $0.02 \%$ and $1.0 \mathrm{~kg} \mathrm{~mL} .^{-1}$ nickel.

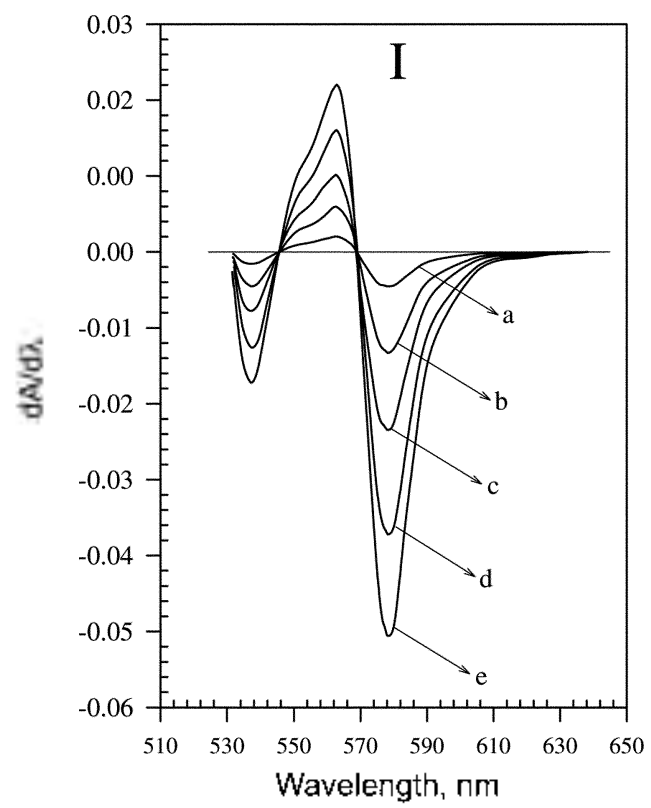

Spectra. Optimum condition $(3.2 \%$ Tween $80,0.02 \%$ $\mathrm{PAN}$ and $\mathrm{pH}$ value of 1.89 ) was applied to obtain zero, first and second derivative spectra of $\mathrm{Ni}(1 \mathrm{l})$-PAN complex. These spectra are given in Figure 1. The suitable wavelengths that can be applied for sensitive zero, first and second derivative determination of nickel are 569,578 and $571 \mathrm{~nm}$, respectively. The overlays of the first and second derivative spectra of Ni(ll)-PAN have been given in Figure 2 when concentration of nickel varies.

Calibration, Accuracy and Precision. The zero, first and second derivative spectrophotometric calibration curves were drawn for determination of nickel at the working wavelengths of 569,578 and $571 \mathrm{~nm}$, respectively. The obtained linear curves are displayed in Table 2 .

Precision and accuracy of the analytical zero, first and second derivative methods were evaluated for five different concentrations of nickel. The results are presented in Table 3 . The obtained results reveal satisfactory reproducibilities and accuracies.

Ten times analysis of a blank (free from nickel) was performed and then spectrophotometric detection limit was evaluated, which was $3 \mathrm{ng} \mathrm{ml} \mathrm{L}^{-1}$ nickel $\left(3 \times \mathrm{S}_{\mathrm{b}}\right)$.

Effects of Foreign Ions. The effects of foreign ions, individually, on the first derivative spectrophotometric

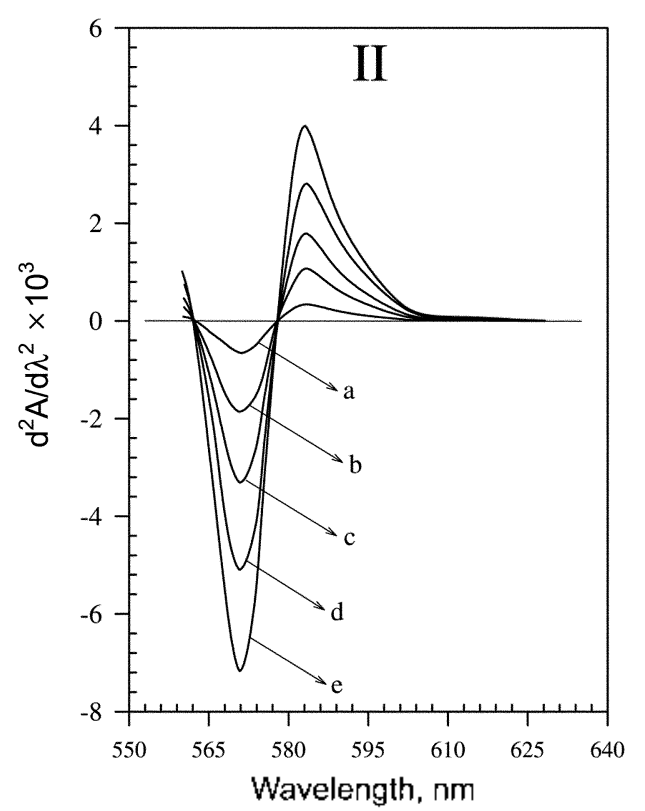

Figure 2. Derivalive spectra of Ni(II)-PAN complex, I) lirst and II) second derivalive spectra of Ni(II)-PAN with concentration of a) 0.1 $\mu \mathrm{g}$

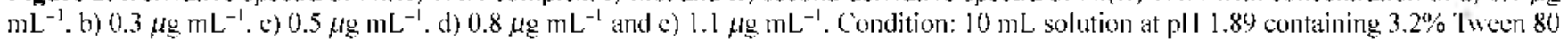
and $0.02 \%$ PAN.

Table 2. Calibration parameters for the determination of nickel

\begin{tabular}{cccc}
\hline \multicolumn{1}{c}{ Calibration equation } & $\begin{array}{c}\text { Wavelength } \\
(\mathrm{nm})\end{array}$ & $\begin{array}{c}\text { Linear range } \\
\left(\mu \mathrm{g} \mathrm{mL}^{-1}\right)\end{array}$ & Regression \\
\hline Abs $2.84 \times 10^{-5}+7.86 \times 10^{-1} \mathrm{C}_{\mathrm{N}_{1}}$ & 569 & $0.03-1.80$ & 0.9997 \\
$\Delta \mathrm{Abs} \Delta \lambda \quad 6.56 \times 10^{-5}+4.56 \times 10^{-2} \mathrm{C}_{\mathrm{N}_{1}}$ & 578 & $0.02-2.50$ & 0.9998 \\
$\Delta^{2} \mathrm{Abs} \Delta \lambda^{2} \quad 2.25 \times 10^{-4}+6.40 \times 10^{-3} \mathrm{C}_{\mathrm{N}_{1}}$ & 571 & $0.03-2.00$ & 0.9998 \\
\hline
\end{tabular}


Table 3. Precision and accuracy of the nickel detemmination method

\begin{tabular}{cccc}
\hline Nickel taken & \multicolumn{3}{c}{ Nickel found $\left(\mu \mathrm{g} \mathrm{mL} \mathrm{m}^{-1}\right)$} \\
\cline { 2 - 4 }$\left(\mu \mathrm{g} \mathrm{mL}{ }^{-1}\right)$ & Spectrophotonetry & $1^{\text {st }}$ Derivative & $2^{\text {nd }}$ Derivative \\
\hline 0.020 & & $0.019 \pm 0.001$ & \\
0.030 & $0.028 \pm 0.001$ & $0.031 \pm 0.002$ & $0.029 \pm 0.001$ \\
1.00 & $1.02 \pm 0.01$ & $0.98 \pm 0.01$ & $0.98 \pm 0.01$ \\
1.80 & $1.82 \pm 0.02$ & $1.77 \pm 0.02$ & $1.83 \pm 0.02$ \\
2.30 & & $2.48 \pm 0.01$ & \\
\hline
\end{tabular}

\pm amounts are standard deviation of eight replicate analysis.

Table 4 . Effect of foreign ions on the first derivative detenmination of $5 \mu$ n nickel

\begin{tabular}{lc}
\hline \multicolumn{1}{c}{ Added ion } & $\begin{array}{c}\text { Tolerance limit } \\
(\mu \mathrm{g} \text { added ion })\end{array}$ \\
\hline $\mathrm{HPO}_{4}{ }^{2-}, \mathrm{ClO}_{3}^{-}, \mathrm{IO}_{3}^{-}, \mathrm{Mg}(\mathrm{II}), \mathrm{NO}_{2}^{-}, \mathrm{SCN}^{-}$, & $>5000$ \\
$\mathrm{~K}(\mathrm{I}), \mathrm{Ca}(\mathrm{II}), \mathrm{F}^{-}, \mathrm{Cl}^{-}, \mathrm{Br}^{-}, \mathrm{I}^{-}$and $\mathrm{CH}_{2} \mathrm{COO}^{-}$ & \\
$\mathrm{Al}(\mathrm{III}), \mathrm{W}(\mathrm{VI}), \mathrm{Sn}(\mathrm{II}), \mathrm{Mo}(\mathrm{VI})$ & 5000 \\
$\mathrm{Cr}(\mathrm{III}), \mathrm{Pb}(\mathrm{II})$ & 2500 \\
$\mathrm{Ag}(\mathrm{I}), \mathrm{Zn}(\mathrm{II}), \mathrm{Cd}(\mathrm{II}), \mathrm{Cr}(\mathrm{VI}), \mathrm{U}(\mathrm{VI}), \mathrm{Hg}(\mathrm{II})^{\alpha}$ & 1000 \\
$\mathrm{Fe}(\mathrm{III}), \mathrm{Mn}(\mathrm{II})$ & 500 \\
$\mathrm{Bi}(\mathrm{III}), \mathrm{Co}(\mathrm{II}), \mathrm{Cu}(\mathrm{II})$ & 250 \\
$\mathrm{Ti}(\mathrm{III}), \mathrm{V}(\mathrm{III})$ & 100 \\
\hline
\end{tabular}

"Masked with iodide $0.01 \mathrm{M}$.

determination of $5 \mu \mathrm{g} \mathrm{Ni}$ was examined. An error of $\pm 3 \mathrm{~S}$ in the absorbance of $5 \mu \mathrm{g}$ nickel, was considered tolerable. The obtained results are shown in Table 4. According to these results. approximately none of the metal ions interfered. which may be due to the low $\mathrm{pH}$ used and the mixture of masking agents added according to the proposed procedure. Copper and cobalt interferences were removed by the addition of $o$-phenantluroline as masking agent (has been given in the procedure). When $o$-phenantluroline is added after addition of PAN, the CO-PAN complex formed is not decomposed. This may be due to oxidation of $\mathrm{CO}$ (II) to Co(III) which produces an inert complex with PAN. Thus 0 phenanthroline must be added before the addition of PAN.

Application. Some synthetic samples according to the composition of some industrial alloys. two different stainless steel samples as well as human hair and tea leaves were analyzed to show the applicability of the determination method.

Synthetic alloy samples were prepared in a manner that their nickel contents were $6 \mu \mathrm{g} \mathrm{mL}^{-1}$. The other metals were adjusted to the appropriate amounts according to their percentage in the Table 5. Then replicate analysis of the solutions was performed using $1.0 \mathrm{~mL}$ of the solution for all of the experiments. The results are given in Table 5 .

Japanese Standards of iron and steel (ISS) CRM 651-7 and 653-7 stainless steel were analyzed for the determination of their nickel contents. $0.0500 \mathrm{~g}$ of the steel was completely digested in $25 \mathrm{~mL}$ hydrochloric acid $(1+1)$ by heating on a hot plate then $1 \mathrm{~mL}$ of $30 \%$ hydrogen peroxide was added to the solution. The heating was continued to decompose the excess hydrogen peroxide. The solution was diluted in a $500.0 \mathrm{~mL}$ volumetric flask with double distilled water after having been cooled. neutralized with sodium hydroxide and filtered. Then $1.0 \mathrm{~mL}$ of the solution was analyzed for the

Table 5. Determination of nickel in some stainless steel and synthetic alloys

\begin{tabular}{|c|c|c|c|}
\hline \multirow{2}{*}{ Sample } & \multicolumn{3}{|c|}{ Nickel found, \% $(\mathrm{n}=6)$} \\
\hline & Spectrophotometry & $\mathrm{l}^{\text {st }}$ Derivative & $2^{\text {uld }}$ Derivative \\
\hline Hastelloy $\mathrm{C}-4$ : & $62.8 \pm 0.5$ & $61.5 \pm 0.4$ & $61.8 \pm 0.7$ \\
\hline $\mathrm{Mo}(15.5 \%), \mathrm{Ni}(62 \%), \mathrm{Cr}(16 \%), \mathrm{Fe}(3 \%)$ & & & \\
\hline Manganin1: & $4.07 \pm 0.05$ & $4.03 \pm 0.05$ & $3.95 \pm 0.04$ \\
\hline $\operatorname{Mn}(12 \%), N i(4 \%), C u(84 \%)$ & & & \\
\hline Alnico $350:$ & $14.9 \pm 0.2$ & $15.2 \pm 0.1$ & $14.8 \pm 0.2$ \\
\hline $\mathrm{Al}(7.8 \%), \mathrm{Ni}(15 \%), \mathrm{Co}(34 \%), \mathrm{Cu}(3.5 \%), \mathrm{Ti}(5 \%), \mathrm{Bal} \mathrm{Fe}$ & & & \\
\hline $\begin{array}{l}\text { Waspaloy: } \\
\mathrm{Ni}(57.5 \%), \operatorname{Co}(13.5 \%), \operatorname{Cr}(19.5 \%), \mathrm{Mo}(4.2 \%), \mathrm{Fe}(1 \%), \operatorname{Al}(1.2 \%), \operatorname{Ti}(3 \%) \text {. }\end{array}$ & $58.1 \pm 0.7$ & $56.8 \pm 0.5$ & $57.1 \pm 0.5$ \\
\hline $\begin{array}{l}\text { Fenicoloy: } \\
\mathrm{Ni}(29 \%), \mathrm{Co}(17 \%), \mathrm{Fe}(53.8 \%), \mathrm{Mn}(0.2 \%)\end{array}$ & $28.9 \pm 0.3$ & $28.7 \pm 0.2$ & $29.3 \pm 0.3$ \\
\hline $\begin{array}{l}\text { Penmute: } \\
\mathrm{Ni}(21 \%), \mathrm{Co}(30 \%), \mathrm{Cu}(49 \%)\end{array}$ & $21.4 \pm 0.3$ & $20.9 \pm 0.2$ & $20.8 \pm 0.2$ \\
\hline $\begin{array}{l}\text { Lemaiguand: } \\
\operatorname{Cu}(39 \%), \operatorname{Ni}(7 \%), \operatorname{Co}(8 \%), \operatorname{Zn}(7 \%), \operatorname{Sn}(9 \%), \operatorname{Fe}(30 \%)\end{array}$ & $7.11 \pm 0.10$ & $7.04 \pm 0.07$ & $6.99 \pm 0.09$ \\
\hline $\begin{array}{l}\text { JSS } 651-7 \text { Stainless Steel: } \\
\mathrm{C}(0.047 \%), \mathrm{Si}(0.072 \%), \mathrm{P}(0.028), \mathrm{Cr}(18.6 \%), \mathrm{S}(0.0063 \%), \mathrm{Mo}(0.84 \%) \\
\mathrm{Al}(0.002 \%), \mathrm{N}(0.0312 \%), \mathrm{C}(0.22 \%), \mathrm{Mn}(1.72 \%), \mathrm{Cu}(0.082 \%), \mathrm{Ni}(9.20 \%)\end{array}$ & $9.38 \pm 0.11$ & $9.31 \pm 0.09$ & $9.25 \pm 0.08$ \\
\hline $\begin{array}{l}\text { JSS } 653-7 \text { Stainless Steel: } \\
\mathrm{C}(0.068 \%), \operatorname{Si}(0.63 \%), \operatorname{Cr}(22.53 \%), \operatorname{Co}(0.35 \%), \mathrm{N}(0.0276 \%), \operatorname{Mn}(1.72 \%) \\
\mathrm{Cu}(0.03 \%), \mathrm{Ni}(13.91 \%)\end{array}$ & $13.75 \pm 0.2$ & $13.81 \pm 0.1$ & $13.79 \pm 0.2$ \\
\hline
\end{tabular}

\pm amounts are standard deriations. 
Table 6. Detenmination of nickel in some biological samples

\begin{tabular}{|c|c|c|c|c|}
\hline \multirow{2}{*}{ Sample } & \multicolumn{4}{|c|}{ Nichel $\left(\mu \mathrm{g} \mathrm{g}^{-1}\right)(\mathrm{n}=5)$} \\
\hline & Certified value & Spectrophotometry & $1^{\text {st }}$ Derivative ${ }^{b}$ & $2^{\text {nd }}$ Derivative \\
\hline NIES No. 7 Tea leaves: & 6.50 & $7.00 \pm 0.31$ & $6.74 \pm 0.19$ & $6.41 \pm 0.21$ \\
\hline $\begin{array}{l}\mathrm{Pb}(0.80), \mathrm{Cd}(0.030), \mathrm{Sb}(0.014), \mathrm{Mg}(1530), \mathrm{Ba}(5.7), \\
\mathrm{K}(18600), \mathrm{Ca}(3200), \mathrm{Cs}(0.22), \mathrm{Co}(0.12), \mathrm{Sc}(0.011), \mathrm{Na}(15.5), \\
\mathrm{Sr}(3.7), \mathrm{Zn}(33), \mathrm{Cr}(0.15), \mathrm{Al}(775), \mathrm{Mn}(7.0), \mathrm{Cu}(7.0) .\end{array}$ & & & & \\
\hline NIES No. 5 Human hair: & 1.80 & $1.90 \pm 0.12$ & $1.72 \pm 0.07$ & $1.89 \pm 0.07$ \\
\hline $\begin{array}{l}\mathrm{Pb}(60), \mathrm{Cd}(0.20), \mathrm{Sb}(0.07), \mathrm{Zn}(169), \mathrm{Al}(240), \mathrm{Sc}(0.05) \\
\mathrm{Fe}(225), \mathrm{Mg}(208), \mathrm{Hg}(4.4), \mathrm{Co}(0.10), \mathrm{Rb}(0.19), \mathrm{K}(34) \\
\mathrm{Mn}(5.2), \mathrm{Cu}(16.3), \mathrm{Ti}(22), \mathrm{Ca}(728), \mathrm{Cr}(1.4), \mathrm{Ba}(2.2), \mathrm{Se}(1.4) \\
\mathrm{Na}(26), \mathrm{Sr}(2.3)\end{array}$ & & & & \\
\hline
\end{tabular}

Table 7. Comparison of some spectrophotometric determination methods of nickel

\begin{tabular}{|c|c|c|c|c|c|c|}
\hline Reagent & Medium/solvent & Interfering ions & $\hat{\lambda}_{\mathrm{ma} \mathrm{a}} / \mathrm{nm}$ & $\begin{array}{c}\varepsilon \times 10^{-1} / \mathrm{L} \\
\mathrm{mol}{ }^{-1} \mathrm{~cm}^{-1}\end{array}$ & $\begin{array}{l}\text { Linear range/ } \\
\mu g \mathrm{~mL}^{-1}\end{array}$ & Ref. \\
\hline 5-Me-BTAMB & Aqueous, SDS & $\mathrm{Cu}(\mathrm{II}), \mathrm{Co}(\mathrm{II}), \mathrm{Pd}(\mathrm{II}), \mathrm{Ag}(\mathrm{I}), \mathrm{Zn}(\mathrm{II}), \mathrm{Fe}(\mathrm{II})$ & 640 & 13.2 & $0.0-0.4$ & 23 \\
\hline 6-Me-BTAMSB & Aqueous, SDS & $\mathrm{Cu}(\mathrm{II}), \mathrm{Co}(\mathrm{II}), \mathrm{Ti}(\mathrm{IV})$ & 620 & 8.22 & $0.0-0.6$ & 24 \\
\hline QADEAP & Aqueous, Tween 80 & $\begin{array}{l}\mathrm{Cu}(\mathrm{II}), \mathrm{Co}(\mathrm{II}), \mathrm{Bi}(\mathrm{III}), \mathrm{Ag}(\mathrm{I}), \mathrm{Fe}(\mathrm{II}), \mathrm{Ag}(\mathrm{I}), \\
\mathrm{Zn}(\mathrm{II}), \mathrm{Fe}(\mathrm{III})\end{array}$ & 590 & 12.3 & $0.0-0.4$ & 25 \\
\hline QADP & Chlorofonm & $\mathrm{Cu}(\mathrm{II}), \mathrm{Co}(\mathrm{II}), \mathrm{Cd}(\mathrm{II}), \mathrm{V}(\mathrm{V}), \mathrm{Zn}(\mathrm{II}), \mathrm{Fe}(\mathrm{III})$ & 574 & 12.4 & $0.0+-0.72$ & 26 \\
\hline PANS & Chlorofonm & $\mathrm{Cu}(\mathrm{II}), \mathrm{Co}(\mathrm{II}), \mathrm{Pd}(\mathrm{II}), \mathrm{Mn}(\mathrm{II}), \mathrm{Zn}(\mathrm{II}), \mathrm{Fe}(\mathrm{III})$ & 570 & 5.6 & $0.1-1.0$ & 27 \\
\hline QADEAA & Aqueous, SDS & $\mathrm{Co}(\mathrm{II}), \mathrm{Ag}(\mathrm{I})$ & 595 & 13.8 & $0.01-0.40$ & 28 \\
\hline PAN & Aqueous, Tween 80 & No interferences & 569 & 4.62 & $0.03-1.80$ & This work \\
\hline
\end{tabular}

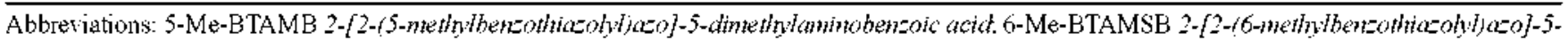

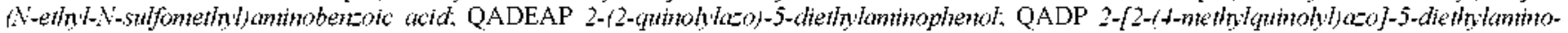
phemot: PANS 1-(2-pyndylazo)-2-maphthot-6-sulfonic acit, QADEAA 2-(2-quinolylazo)-5-diethylaminoaniline.

determination of nickel. The obtained results are given in Table 5 .

A $5.0 \mathrm{~g}$ human hair and tea leaves were put in $50 \mathrm{~mL}$ round-bottom flasks and digested in $15 \mathrm{~mL}$ concentrated nitric acid after $3 \mathrm{hrs}$ heating. The solution was cooled. neutralized with sodium hydroxide and filtered. The filtrate was made up to $25 \mathrm{~mL}$ in a volumetric flask with double distilled water $0.5-1.5 \mathrm{~mL}$ of the solution was analyzed by the standard addition method. The results are given in Table 6 .

\section{Conclusions}

A sensitive and selective zero. first and second derivative spectrophotometric method was established for the determination of nickel using PAN in Tween 80 micellar media. The proposed method was applied to assays of nickel in the various biological samples and alloys. The analytical results were satisfactory. The proposed method should be useful for accurate. precise. rapid and simple determination of nickel.

Finally. some important features of the proposed method in comparison with the other methods that use some multidentate azo compounds as complexing chromogenic agent have been given in Table 7 .

Acknow ledgement. The author wishes to thank Dr. Usha Barahnand for her genereous help in correction of the manuscript and the financial support of this work by the University of Mohaghegh Ardebili.

\section{References}

1. Cammack. R.: vanVlient. P. V: Reedijk. J: Bouwman. E Bioinorganic Catalysis: Marcel Dekker: New York. U. S. A.. 1999: pp 231-233

2. Ermler. U.: Grabarse. W.: Shima. S.: Goubeaud. M.: Thauer. R. K. Curr: Op. Siruct. Biol 1998. 8.749.

3. Dole. F: Medina, M: More, C.: Cammack. R.: Bertrand. P: Guigliarelli. B. Biochemistry 1996. 35. 16399.

4. Andrews. R. K.: Blakeley. R. L.: Zerner. B.: Lancaster. T. R. The Bioinorganic Chemistry of Nickel. VCH Publishers: New York. U. S. A., 1988: pp 141-165.

5. Telser, J. Sthtct. Bonding 1998, 91.31

6. Ralston. C. Y; Wang. H.; Ragsdale, S. W: Kumar, M.: Spangler. N. J.: Ludden. P. W.: Gu. W.: Jones. R. M.: Patil. D. S.: Cramer. S P. J. Am. Chem. Soc. 2000. 122. 10553

7. Ragsdale. S. W. Kumar. M. Chem. Rsv 1998.96.2515.

8. Youn. H.-D.: Kim. E.-H.: Roe. J.-H.: Kang. S.-O. Biochem. J. 1996. 318,889

9. Choudhury, S. B.: Lee. J.W.: Davidson, G.; Ym, Y.-I.: Bose, K.; Sharma. M. L.: Kang. S.-O.: Cabelli. D. E.: Maroney. M. J. Biochemisty 1999. 38. 3744.

10. Sirko. A.: Brodzik. R. Acta Biochim. Pol. 2000. 47. 1189.

11. Greenwood, N. N.; Earnshaw, A. Chentisty of the Elentents; Pergamon Press: Oxford. U. K.. 1985; pp 1330-1331.

12. Chen. J: Teo. K. C. Anal Chim Acta 2001. 134,325

13. Kumar. M.: Rathore. D. P. S.: Singh. A. K. Talanta 2000. 51. 
1187

14. Ma. R.: Adams. F. And Chim .Acta 1995. 317.215.

15. Tewari. P. K.: Singli. A. K. Anatyst 1999, 124, 1847.

16. Gonzalez. M: Gallego. M: Valcarcel. M. Talanta 1999. t8. 1051.

17. Zendelovska. D.: Pavlovska. G.: Cundeva, K.: Statilow, T. Totonta 2001. 54. 139.

18. Sandell. E. B. Colorimetric Determination of Traces of Metals. $3^{\text {nd }}$ Ed.: Interscience Publishers: New York. U. S. A.. 1959.

19. Ferreira. S. L. C.: Spinola Costa. A. C.: de Jesus, D. S. Talonta $1996,+3,1649$

20. Sandell. E. B. Colorimetric Determination of Traces of Metals: Interscience Publishers: New York. U. S. A. 1959: pp 665673.
21. Lee. S. K.: Choi. H. S. Bull. Konam Chem. Soc. 2001. 22.463.

22. Eskandari. H.: Imanzadeh Karkaragh. G. Bull. Korean Chem. Soc. 2003. $2+, 1731$.

23. Fan, X. Z.; Zhu. C. H.: Zhang, G. F. Analyst 1998. 123, 109.

24. Fan, X. Z. Zhu. C. H. Mfrochem. J. 1998. 59.284.

25. Hu. Q. F.: Yang. G. Y.: Tang. D. Y.: Yin. J. Y. Fenxi Huaxue 2002. 30.699 .

26. Zhao. S. L.: Xia. X. Q.: Ma. H. R.: Xi. H. J. Talanta 1994. 4 . 1353 .

27. Ohshita. K; Wada. H.; Nakagawa. G. Anal. Chm defa 1982. $1+0$. 291.

28. Hu. Q. F.: Yang. G. Y.: Huang. Z. T.: Yin. . Y. Y. Anat Sci. 2003.19. 1449. 